\title{
PATTERNS OF CHEMICAL CONTROL OF WEEDS ON DISC ON PRODUCTION AND RAINFALL AND RAIN DAYS AT KUALA PESILAM GARDEN GARDEN ELEPHANT HALL DIVISION I PT. BAHRUNY
}

\author{
Rina Maharany', Dina Arfianti Saragih², Delyana R Pulungan³ ${ }^{3}$ Ika Ucha Pradifta ${ }^{4}$, \\ Muhammad Kahfi Adam 5 \\ 1,2,3,5 Program Studi Budidaya Perkebunan, Sekolah Tinggi Ilmu Pertanian Agribisnis Perkebunan, Medan, \\ Indonesia \\ ${ }^{4}$ Program Studi Teknologi Pengolahan Hasil Perkebunan, Sekolah Tinggi Ilmu Pertanian Agribisnis \\ Perkebunan, Medan, Indonesia \\ E-mail: ${ }^{3)}$ delpulungan@stipap.ac.id
}

\begin{abstract}
This final project research was conducted at the Kuala Pesilam Balai Gajah estate, Division I, PT. Bahruny, North Sumatra Province. This study took place from July to July 2021. This study aims to determine the pattern of weed control in the circle on production as well as rainfall and rainy days. This study uses a descriptive method by collecting secondary data from the garden: rainfall and production data. The results of this study can indicate that Indonesia's unstable palm oil production is caused by several factors, namely genetic factors, biotic factors (weeds) and abiotic factors (rainfall and rainy days). Production in 2020 is the highest production of oil palm for 4 years (20172020) with a total production of 5,971,760 Kilograms with an area of 336.96 hectares. The amount of rainfall is $2371 \mathrm{~mm}$ and rainy days is 117 days with weed control patterns on the disk carried out 4 times a year. Production in 2018 was the lowest production of oil palm for 4 years (2016-2020) with a total production of 4,032,338 kg, with an area of $267.96 \mathrm{Ha}$. The amount of rainfall is 1854 mm and rainy days is 112 rainy days with weed control patterns on the disc 2 times a year. The optimal rainfall for the growth and production of oil palm plants is 2,000 $\mathrm{mm}$, but with $1846 \mathrm{~mm}$ of rainfall it does not mean it is not good for the growth and production of oil palm plants as long as there is no water deficit, so this rainfall is still included in the criteria for growing oil palm. Production in 2018 was the lowest production of oil palm for 4 years (2016-2020) with a total production of 4,032,338 kg, with an area of $267.96 \mathrm{Ha}$. The amount of rainfall is $1854 \mathrm{~mm}$ and rainy days is 112 rainy days with weed control patterns on the disc 2 times a year. The optimal rainfall for the growth and production of oil palm plants is $2,000 \mathrm{~mm}$, but with $1846 \mathrm{~mm}$ of rainfall it does not mean it is not good for the growth and production of oil palm plants as long as there is no water deficit, so this rainfall is still included in the criteria for growing oil palm. Production in 2018 was the lowest production of oil palm for 4 years (2016-2020) with a total production of 4,032,338 kg, with an area of $267.96 \mathrm{Ha}$. The amount of rainfall is $1854 \mathrm{~mm}$ and rainy days is 112 rainy days with weed control patterns on the disc 2 times a year. The optimal rainfall for the growth and production of oil palm plants is 2,000 mm, but with $1846 \mathrm{~mm}$ of rainfall it does not mean it is not good for the growth and production of oil palm plants as long as there is no water deficit, so this rainfall is still included in the criteria for growing oil palm.
\end{abstract}

Keywords: Cost Assessment, Disc Maintenance, Oil Palm

\section{INTRODUCTION}

Currently, oil palm is in great demand to be managed and planted. Due to the attractiveness of planting oil palm is still a mainstay source of vegetable oil and agro-industry materials. The high growth of the palm oil industry is a positive thing that needs to be maintained and improved. Efforts to maintain and increase plant productivity can be done through proper maintenance activities. One 
Patterns Of Chemical Control Of Weeds On Disc On Production And Rainfall And Rain Days At Kuala Pesilam Garden Garden Elephant Hall Division I PT. Bahruny

of the elements of maintaining oil palm plantations during the mature crop (TM) period is weed control (Sarjono and Zaman, 2017).

Oil palm is a plant that is cultivated in plantations. To be able to grow and produce optimally, it is necessary to pay attention to several influencing factors. Climatic and soil conditions are the main factors that influence oil palm growth in addition to other factors such as genetic factors and agronomic-technical factors and factors (Indriarta, 2019).

\subsection{Climate Condition}

Factors of climatic conditions are very influential on the growth and production of oil palm. Oil palm is a tropical plant that grows well in areas located between 15 o North Latitude - 15o South Latitude, especially in Africa, Asia and Latin America (Indriarta, 2019).

1. Rainfall

Rainfall is good for the growth and production of oil palm plantations - an average of 2,000$2,500 \mathrm{~mm}$ per year with an even distribution throughout the year. Even rainfall can reduce soil evaporation. Rain that does not fall for several months will cause stunted leaf bud growth until it rains. Water is a solvent for nutrients in the soil, so with the help of water these elements will be available to plants. If the soil is dry, plant roots will find it difficult to absorb mineral ions from the soil. Too much rain will not adversely affect fruit production (Indriarta, 2019). Rainfall that is less than $2,000 \mathrm{~mm}$ per year does not mean it is not good for oil palm growth, as long as there is no water deficit (Raharja, 2019).The optimal monthly rainfall for oil palm is $100-200 \mathrm{~mm}$ per month or 50 $\mathrm{mm}$ per 10 days or the soil conditions are still quite wet (Gapki, 2020). The presence of weeds in oil palm plantations can lead to a decrease in the quantity and quality of fresh fruit bunches (FFB) production, disturbance to plant growth, increased pest and disease attacks, disturbance of water use and in general will increase the cost of farming (Pahan, 2006).

\section{IMPLEMENTATION METHOD}

This study uses a descriptive analysis method, namely by taking secondary garden data, namely: data on the cost of herbicide materials, data on the cost of weed spraying power, and data on the cost of spraying equipment, controlling weeds in the pikul market by chemical means on oil palm plants (Elaeis guineensis Jacq).

\subsection{Research Parameters}

a. Chemical weed control patterns on rainfall and rainy days power, and data on the cost of spraying equipment, controlling weeds in the pikul.

b. Chemical weed control pattern of weeds on oil palm crop production.

\section{RESULTS AND DISCUSSION}

\subsection{Patterns of Control of Weeds in Dish With Chemical Methods on Rainfall and Raind Days}

In the implementation of weed control on disks by chemical means, we can see the pattern of weed control on rainfall and rainy days at the Kuala Pesilam Balai Gajah Plantation, PT. Bahruny : 


\section{ORFAI JOURNAL Actual and International Issue}

Table1 Rainfall And Rainy Days For 5 Years (2017-2020)

\begin{tabular}{|c|c|c|c|c|c|c|c|c|c|c|c|c|}
\hline \multirow[t]{3}{*}{ BLN } & \multicolumn{12}{|c|}{ Year } \\
\hline & \multicolumn{2}{|c|}{2017} & \multicolumn{2}{|c|}{2018} & \multicolumn{2}{|c|}{2019} & \multicolumn{2}{|c|}{2020} & \multicolumn{2}{|c|}{2021} & \multicolumn{2}{|c|}{ Average } \\
\hline & $\begin{array}{c}\text { CH } \\
(\mathbf{m m})\end{array}$ & HH & $\begin{array}{c}\text { CH } \\
(\mathbf{m m})\end{array}$ & HH & $\begin{array}{c}\text { CH } \\
(\mathbf{m m})\end{array}$ & HH & $\begin{array}{c}\text { CH } \\
(\mathbf{m m})\end{array}$ & HH & $\begin{array}{c}\text { CH } \\
(\mathbf{m m})\end{array}$ & HH & $\begin{array}{c}\text { CH } \\
(\mathbf{m m})\end{array}$ & HH \\
\hline Jan & 152 & 11 & 106 & 11 & 49 & 4 & 2 & 1 & 285 & 15 & 119 & 8 \\
\hline Feb & 131 & 4 & 132 & 4 & 155 & 4 & 65 & 6 & 144 & 4 & 125 & 4 \\
\hline Mar & 73 & 11 & 43 & 2 & 14 & 2 & 43 & 2 & 126 & 11 & 60 & 6 \\
\hline April & 195 & 14 & 171 & 11 & 39 & 5 & 110 & 5 & 86 & 6 & 120 & 8 \\
\hline May & 267 & 9 & 49 & 10 & 343 & 14 & 288 & 12 & 53 & 7 & 200 & 10 \\
\hline Jun & 155 & 10 & 80 & 7 & 206 & 11 & 276 & 13 & 138 & 3 & 179 & 10 \\
\hline Jul & 168 & 12 & 103 & 7 & 85 & 7 & 128 & 6 & - & - & 121 & 8 \\
\hline Aug & 322 & 14 & 75 & 5 & 49 & 6 & 95 & 6 & - & - & 135 & 8 \\
\hline Sep & 276 & 18 & 394 & 16 & 167 & 12 & 443 & 14 & - & - & 320 & 15 \\
\hline Oct & 334 & 14 & 362 & 18 & 125 & 15 & 394 & 19 & - & - & 304 & 17 \\
\hline Nov & 181 & 11 & 178 & 10 & 290 & 13 & 260 & 16 & - & - & 227 & 13 \\
\hline Des & 285 & 17 & 161 & 11 & 188 & 11 & 267 & 17 & - & - & 225 & 14 \\
\hline JLH & 2539 & 145 & 1854 & 112 & 1710 & 104 & 2371 & 117 & 694 & 43 & 2136 & 121 \\
\hline
\end{tabular}

Table 1 shows that the highest rainfall for 5 years (2017-2021) occurred in 2017 which was $2539 \mathrm{~mm}$, while the lowest rainfall for 5 years (2017-2021) occurred in 2021 by $694 \mathrm{~mm}$. The low rainfall that occurred in 2019 was $1710 \mathrm{~mm}$.

Table 1 also shows that the highest rainy day for 5 years (2017-2021) occurred in 2017 which was 145 rainy days, while the lowest rainy day for 5 years (2017-2021) occurred in 2019 of 104. Rainfall data and days Rainfall for 5 Years (2017-2021) is also presented in Figure 1.

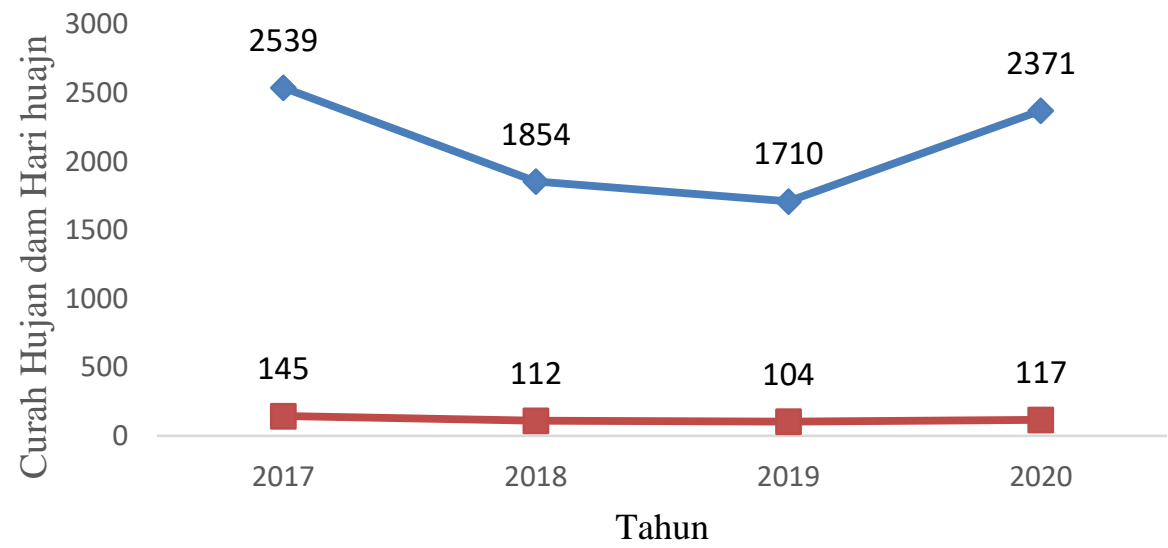

Picture 1Graph of Rainfall and Rainy Days for 5 Years (2017-2021) PT. Bahruny Kebun Kuala Pesilam Elephant Hall

Figure 1 shows that the rainfall that occurred in 2017 was the highest rainfall for 4 years (20172020) with a rainfall intensity of $2539 \mathrm{~mm}$, where this amount of rainfall has met the requirements for growth and production of oil palm plants. This is supported by Indriarta (2019) which states that good rainfall for oil palm growth and production averages 2,000-2,500 $\mathrm{mm}$ per year with an even distribution throughout the year. Likewise, the rainy day that occurred in 2017 was the highest rainy day for 5 years (2017-2021) with a total of 145 rainy days. Hartanto (2011) states that the number of rainy days is not more than 180 rainy days per year. This also affects the pattern of weed control in the disk where in 2017 the weed control pattern is carried out 2 times a year. This is due to high 
Patterns Of Chemical Control Of Weeds On Disc On Production And Rainfall And Rain Days At Kuala Pesilam Garden Garden Elephant Hall Division I PT. Bahruny

Rina Maharany, Dina Arfianti Saragih, Delyana R Pulungan, Ika Ucha Pradifta, Muhammad Kahfi Adam

rainfall, because one of the weaknesses in chemical weed control is high rainfall, because it can cause leaching or washing of herbicides so that the application is not effective. This is supported by Khalil et al, (2019). Stated that the weather, especially the high intensity of rainfall, was one of the factors causing the washing of herbicides from the surface of weeds. This also resulted in high material and labor costs, due to the high intensity of rainfall and rainy days in 2017. because one of the weaknesses in chemical weed control is high rainfall, because it can cause leaching or washing of herbicides so that the application is not effective. This is supported by Khalil et al, (2019). Stated that the weather, especially the high intensity of rainfall, was one of the factors causing the washing of herbicides from the surface of weeds. This also resulted in high material and labor costs, due to the high intensity of rainfall and rainy days in 2017. because one of the weaknesses in chemical weed control is high rainfall, because it can cause leaching or washing of herbicides so that the application is not effective. This is supported by Khalil et al, (2019). Stated that the weather, especially the high intensity of rainfall, was one of the factors causing the washing of herbicides from the surface of weeds. This also resulted in high material and labor costs, due to the high intensity of rainfall and rainy days in 2017. Stated that the weather, especially the high intensity of rainfall, was one of the factors causing the washing of herbicides from the surface of weeds.

This also resulted in high material and labor costs, due to the high intensity of rainfall and rainy days in 2017. Stated that the weather, especially the high intensity of rainfall, was one of the factors causing the washing of herbicides from the surface of weeds. This also resulted in high material and labor costs, due to the high intensity of rainfall and rainy days in 2017. 2019 was the lowest rainfall for 4 years (2017-2020) of $1710 \mathrm{~mm}$. according to Raharja, (2019) states that rainfall of less than 2,000 mm per year does not mean it is not good for oil palm growth, as long as there is no water deficit. So that the rainfall in 2019 is still classified as the criteria for growing oil palm plantations. Likewise, the rainy days in 2019 amounted to 112 days. Hartanto (2011) states that the number of rainy days is no more than 180 rainy days per year. This affects the pattern of weed control in the disk where in 2019 the weed control pattern is carried out 4 times a year. This causes the cost of materials and labor to control weeds on the disc issued is not too large.

\subsection{Pattern Of Control Of Weeds On Disc By Chemical Way To Production For 4 Years (2017- 2020) Division I Pt. Bahruny}

In the implementation of weed control on disks by chemical means, we can see the pattern of weed control on production at the Kuala Pesilam Balai Gajah Plantation, PT. Bahruny is presented in table 2:

Table 2 Production of Oil Palm Plants for 4 Years (2017-2020)

\begin{tabular}{cccc}
\hline Year & Production $(\mathbf{K g})$ & Area $($ Ha) & Productivity/Ha $(\mathbf{K g})$ \\
\hline $\mathbf{2 0 1 7}$ & $4,510,533$ & 177.28 & 25,442 \\
$\mathbf{2 0 1 8}$ & $4,032,338$ & 267.96 & 15,048 \\
$\mathbf{2 0 1 9}$ & $4,962,962$ & 336.96 & 14,728 \\
$\mathbf{2 0 2 0}$ & $5,971,760$ & 336.96 & 17,722 \\
Amount & $\mathbf{2 2 , 6 0 9 , 5 8 8}$ & $\mathbf{1 , 4 9 4 . 4 6}$ & $\mathbf{8 1 . 2 8 5}$ \\
Average & $\mathbf{4 , 5 2 1 , 9 1 7 . 6}$ & $\mathbf{2 9 8 . 8 9}$ & $\mathbf{1 6 , 2 5 7}$ \\
\hline
\end{tabular}

Table 2. shows that the highest production of oil palm for 5 years (2017-2021) occurred in 2020, which was 5,971,760 kilograms, while the lowest production of oil palm for 5 years (20172021) occurred in 2018 of 4,032. 338 kilograms. The low productivity of oil palm plantations that occurred in 2018 was due to the fact that this year was the current year. Production data for 5 years (2017-2021) is also presented in Figure 2: 


\section{M}

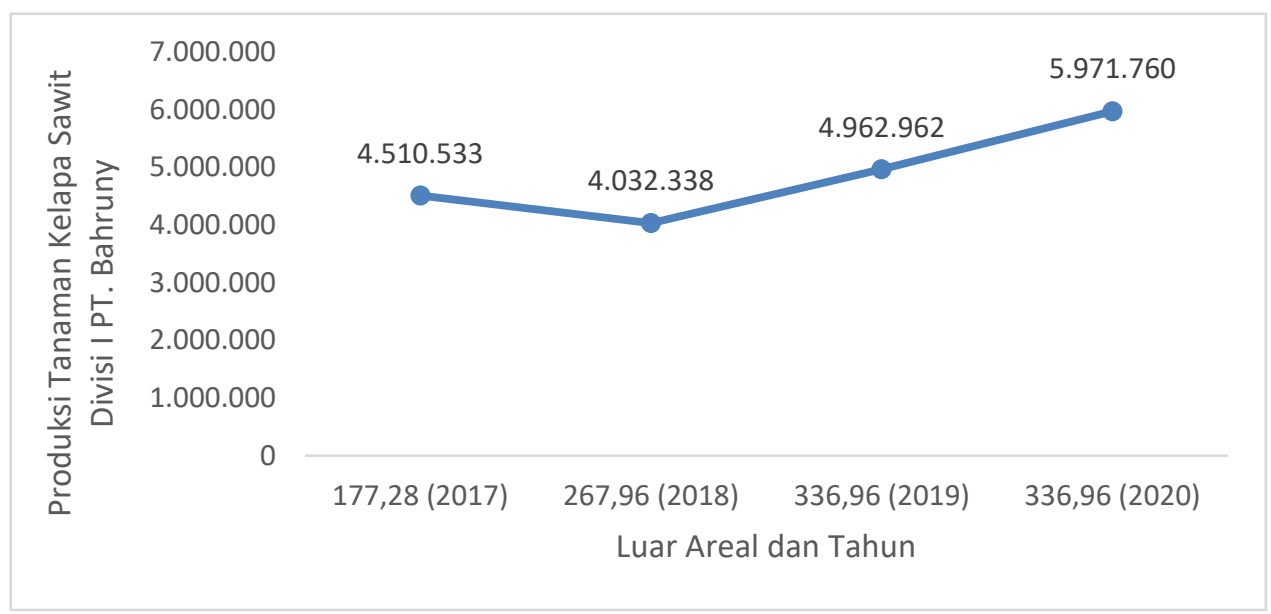

Picture 2 FFB productivity for 5 years

Production in 2020 was the highest for 5 years (2017-2021), which was 5,971,760 kilograms. With an area of $336.96 \mathrm{Ha}$. this is supported by Nuvfitarini et al, (2016) stating that the increase in the area of oil palm plantations is also balanced with an increase in oil palm productivity. With rainfall of $2371 \mathrm{~mm}$ and 117 rainy days. Based on data from the company, in 2020 weed control activities on discs are carried out 4 times a year, this can also affect the increase in oil palm production due to the lack of competition between oil palm plants and weeds in the area. dish. This is also supported by Nuvfitarini et al, (2016) which states that the presence of weeds in plantations can reduce production because weeds compete with cultivated plants for water, sunlight, nutrients, air and growing space. This causes the growth of cultivated plants to be disrupted, so that it can reduce production yields.

In 2018 the production of oil palm plantations was 4,032,338 kilograms, with an area of 267.96 hectares, according to Nuvfitarini et al, (2016) affect the increase in production due to reduced competition between oil palm plants and weeds. This is also supported by Nuvfitarini et al, (2016) who stated that the presence of weeds in plantations can reduce production because weeds stating that the increase in the area of oil palm plantations was also balanced with an increase in oil palm productivity. With $1854 \mathrm{~mm}$ of rainfall and 112 rainy days of rain. In 2019 the weed control pattern on the disc is 2 times a year, this is also direct compete with cultivated plants for water, sunlight, nutrients, air and growing space. This causes the growth of cultivated plants to be disrupted, so that it can reduce production yields.

\section{CONCLUSION}

Production in 2020 was the highest oil palm crop for 4 years (2017-2020) with a total production of 5,971,760 kg, with a total area of $336.96 \mathrm{Ha}$. Rainfall occurred at $2371 \mathrm{~mm}$ and rainy days 117 days with weed control patterns on disks carried out 4 times a year. Production in 2018 was the lowest production for 4 years (2017-2020) with a total production of 4,032,338 kg, with an area of $267.96 \mathrm{Ha} .1854 \mathrm{~mm}$ of rainfall and 112 days of rain with a weed control pattern on the disc was carried out 2 times a year. The optimal rainfall for the growth and production of oil palm is 2,000 $\mathrm{mm}$ but with 1846 rainfall it does not mean that it is not good for oil palm plant growth as long as there is no water deficit.

\section{REFERENCES}

Gapki., 2020. Ngobrol Bareng Gapki Prediksi Kemarau 2020 Dan Dampaknya Bagi Perkebunan Kelapa Sawit.

Indriarta, A. Nabila., 2019. Kelapa Sawit : Budi daya dan pengolahannya. Loka Aksara. Tanggerang. 
Patterns Of Chemical Control Of Weeds On Disc On Production And Rainfall And Rain Days At Kuala Pesilam Garden Garden Elephant Hall Division I PT. Bahruny

Nuvitarini, W., Zaman, S., dan Junaedi A. 2016. Pengelolaan Gulma Kelapa Sawit Studi Kasus Di Kalimatan Selatan : Bul. Agronomi 4(1) : 29-36.

Sarjono, B. Y. dan Zaman, S. 2017. Pengendalian Gulma pada Perkebunan KelapaSawit (Elaeis guineensisJacq.) di Kebun Bangun Koling. Bul. Agrohorti 5(3): 384-391.

Hartanto, (2011), Sukses Besar Budidaya Kelapa Sawit, Penerbit Citra Media, Yogyakarta.

Indriarta, A. Nabila., 2019. Kelapa Sawit : Budidaya dan pengolahannya. Loka Aksara. Tanggerang.

Raharja, Hanang Slamet. 2019. Budi Daya Tanaman Kelapa Sawit. Jakarta Barat : PT Sunda Kelapa Pustaka. 